\title{
FOXP3 Gene
}

National Cancer Institute

\section{Source}

National Cancer Institute. FOXP3 Gene. NCI Thesaurus. Code C104394.

This gene is involved in transcription regulation and the immune response. 